Cakrawala Dini: Jurnal Pendidikan Anak Usia Dini| p-ISSN2087-I317 | e-ISSN 2621-8321

Vol. II. No.2 November 2020 | Hal 76-87

\title{
PENGEMBANGAN ALAT PERMAINAN KARTU $U$-KIDS (UNO KIDS) UNTUK MENSTIMULASI KECERDASAN LOGIS- MATEMATIS ANAK USIA 5-6 TAHUN
}

\author{
Asthiani Kholida ${ }^{1}$, I Wayan Sutama ${ }^{2}$, Suryadi ${ }^{3}$ \\ 1,2, 3 Universitas Negeri Malang
}

\begin{abstract}
Every child has a future that is inseparable from the stimulation of the development. The scope of cognitive development is closely related to logicalmathematical intelligence children aged 5-6 years are at the stage of pre-commercial play that begins to require creative material to think concretely and thus requires educational play tools. In fact the use of educational play tools to stimulate logicalmathematical intelligence of children aged 5-6 years in some early childhood education institutions is still not optimal. This is the background of researcher in developing U-Kids card game tools effective, efficient and attractiveto stimulate logical-mathematical intelligence of children aged 5-6 years. This research and development uses the ADDIE development model. These results indicate that the U-Kids card game tool has a percentage of eligibility of 90,7\% (very feasible) with an effectiveness aspect of 92,22\% (very effective), an efficiency aspect of 90,95\% (very efficient) and an attractiveness aspect of $88,88 \%$ (very attractiveness). Based on these results it can be concluded that the development of the U-Kids card game tool to stimulate logical-mathematical intelligence of children aged 5-6 years is very valid in terms of effectiveness, efficiency and attractiveness.
\end{abstract}

Keyword: logical-mathematical intelligence, children aged 5-6 years, U-Kids card game tool.

\begin{abstract}
Abstrak: Setiap anak memiliki masa depan yang tidak terlepas dari rangsangan perkembangan. Lingkup perkembangan kognitif berkaitan erat dengan kecerdasan logismatematis anak usia 5-6 tahun berada pada tahap bermain praopersaional yang mulai berpikir kreatif sehingga memerlukan alat permainan edukatif. Namun, pada kenyataannya penggunaan alat permainan edukatif untuk menstimulasi kecerdasan logismatematis anak usia 5-6 tahun di beberapa lembaga PAUD masih belum optimal. Hal ini melatar belakangi peneliti untuk mengembangkan alat permainan kartu U-Kids (UNO Kids) yang efektif, efisien dan menarik untuk menstimulasi kecerdasan logis-matematis anak usia 5-6 tahun. Penelitian dan pengembangan ini menggunakan model pengembangan ADDIE. Hasilnya menunjukan bahwa kartu U-Kids memiliki persentase kelayakan sebesar 90,7\% (sangat layak) dengan aspek keefektifan sebesar 92,22\% (sangat efektif), aspek keefisienan 90,95\% (sangat efisien) dan aspek kemenarikan 88,88\% (sangat menarik). Berdasarkan hasil tersebut dapat disimpulkan bahwa pengembangan alat permainan kartu $U$-Kids untuk menstimulasi kecerdasan logis-matematis anak usia 56 tahun sangat valid dari segi efektifitas, efisiensi dan kemenarikan.
\end{abstract}

Kata Kunci: kecerdasan logis-matematis, anak usia 5-6 tahun, alat permainan kartu $U$ Kids.

\footnotetext{
' Universitas Negeri Malang, Email: asthiani.kholida.160153601260国um.ac.id

2Universitas Negeri Malang, Email: wayan.sutama.fip回um.ac.id

${ }^{3}$ Universitas Negeri Malang, Email: suryadi.fip回um.ac.id
} 


\section{PENDAHULUAN}

Setiap anak memiliki masa depan yang tidak terlepas dari rangsangan perkembangan di lingkungan sekitar, baik rangsangan eksternal maupun internal. Lingkup pengembangan kognitif untuk anak usia dini dalam Peraturan Menteri Pendidikan dan Kebudayan Nomor 137 Tahun 2014 tentang Standar Nasional berkaitan erat dengan kecerdasan logis-matematis. Seperti yang dikemukakan oleh Musfiroh (2014) bahwa pengembangan kognitif berkaitan erat dengan kecerdasan logis-matematis. Stimulasi kecerdasan logis-matematis dapat mendorong perkembangan kognitif anak, terutama dalam hal berpikir logis, mengolah informasi, kapasitas berpikir. Jasmin (2001) mengemukakan bahwa kecerdasan logis-matematis dapat menjamin keberhasilan dalam persaingan sekolah lebih tepatnya menjamin keberhasilan dalam tes-tes IQ (intelligence quotient) dan SAT (Student Aptitude Test). Itulah sebabnya kecerdasan logis-matematis sangat penting untuk keberhasilan anak di bidang akademis.

Anak usia 5-6 tahun berada pada tahap bermain praopersaional. Purnama, Hijriyani, dan Heldanita (2019) menyebutkan bahwa anak usia 5 tahun mulai memerlukan materi kreatif sehingga diperlukan alat bermain yang bersifat edukatif. Untuk itu alat permainan edukatif berperaan penting dalam perkembangan anak usia dini yang mulai berpikir konkrit. Selain sebagai media pembelajaran alat permainan edukatif juga dapat meningkatkan antusias anak usia dini untuk belajar. Alat permainan edukatif merupakan alat yang digunakan anak untuk memenuhi keinginan bermain, sehingga memberikan informasi, mengembangkan aspek perkembangannya, menghasilkan pengertian, dan memberikan kesenangan (Kustiawan, 2013). Pendapat tersebut menegaskan bahwa selain hanya untuk kesenangan, alat permainan edukatif juga dapat menstimulasi perkembangan anak sejak dini.

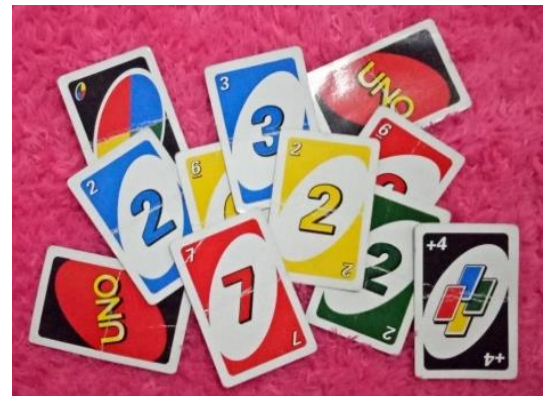

Gambar 1. Kartu UNO

Tidak sedikit yang menganal alat permainan kartu UNO. Witantyo (2017) menyebutkan bahwa seiring dengan ditetapkannya kartu UNO sebagai International Game Inc., pada tahun 2010 permainan kartu UNO tergolong popular di dunia, termasuk di Indonesia. Kartu UNO juga menarik perhatian beberapa peneliti untuk mengembangkannya. Namun, sejauh ini peneliti belum menemukan pengembangan kartu UNO untuk ranah pendidikan anak usia dini. Seperti yang dilakukan oleh Witantyo (2017) yang terbatas pada mata pelajaran Akuntansi Perusahaan Jasa, sehingga alat permainan ini tidak dapat digunakan untuk banyak kalangan terutama anak usia dini. Begitu pun penelitian yang dilakukan oleh Hidayati (2014) yang terbatas pada pembelajaran akuntansi dengan materi hutang jangka panjang, tentu saja kurang tepat jika digunakan untuk anak usia dini.

Pentingnya penggunaan alat permainan edukatif untuk menstimulasi kecerdasan logis-matematis anak usia 5-6 tahun mengharuskan lembaga PAUD memiliki alat permainan tersebut. Namun pada kenyataannya, penggunaan alat permainan edukatif untuk menstimulasi kecerdasan logis-matematis anak usia 5-6 tahun di beberapa lembaga PAUD masih belum optimal. Hal ini melatar belakangi peneliti dalam mengembangkan alat permainan kartu U-Kids (UNO Kids) yang efektif, efisien dan menarik untuk menstimulasi kecerdasan logis-matematis anak usia 5-6 tahun. 
TINJUAN PUSTAKA

\section{Bermain dan Permainan}

Bermain merupakan salah satu kebutuhan manusia sepanjang hidupnya. Di Indonesia misalnya, seorang bayi diajak bermain ciluk baa atau pok ameame, menjelang di masa remaja seorang anak dapat bermain layang-layang bahkan bersepeda, hingga menginjak dewasa seseorang mampu bermain catur dan bermain sepak bola (Musfiroh, 2005). Melalui bermain seseorang tidak hanya menikmati permainan mareka sendiri, tetapi bisa jadi terpesona oleh permainan orang lain. Untuk itu, suatu kegiatan bisa dikatakan bermain apabila seseorang melakukannya dengan tujuan kesenangan bukan karena paksaan.

Pentingnya kegiatan bermain bagi anak usia dini tidak terlepas dari manfaat bermain itu sendiri. Manfaat bermain menurut Purnama, Hijriyani, dan Heldanita (2019) adalah: melatih kemampuan motorik; melatih konsentrasi; meningkatnya kemamapuan sosialisasi (termasuk berkompetisi); melatih keterampilan bahasa; mengembangkan kemampuan kognitif, dan; mengembangkan kemampuan afektif. Manfaat bermain bagi anak tersebut berpengaruh dalam kehidupan anak di masa yang akan datang. Dengan demikian bermain dapat dijadikan metode pembelajaran dalam kegiatan stimulasi di lembaga PAUD.

Tingkat usia anak berpengaruh pada tahapan perkembangan bermainnya. Purnama, Hijriyani, dan Heldanita (2019) menyebutkan pendapat Piaget mengenai tahap bermain anak usia 5-6 tahun yang berada pada tahap praoperasional. Pada tahap ini anak mulai memerlukan materi kreatif sehingga diperlukan alat bermain yang bersifat edukatif. Purnama, Hijriyani, dan Heldanita (2019) juga menyebutkan bahwa usia 5-6 tahun anak berada pada puncak bermain dengan barang. Untuk itu dibutuhkan alat permainan edukatif untuk menstimulasi perkembangannya.
Permainan dikatakan sebagai konsep bermain jika memiliki aturan dengan maksud mencapai tujuan permaianan tersebut. Hidayatu (2017) mengungkapkan bahwa permainan untuk anak usia dini ini adalah permainan yang dapat merangsang kreativitas dan menyenangkan bagi anak. Selain itu Hurlock (2016) berpendapat bahwa permainan yang dilakukan oleh anak usia dini bersifat spontan dan informal. Bisa disimpulkan bahwa permainan bagi anak usia dini berlangsung sesuai keinginan mereka secara spontan dan dapat merangsang kreativitas serta menyenangkan bagi anak.

Ada beberapa jenis permainan yang berperan penting bagi perkembangan anak. Menurut Purnama, Hijriyani, dan Heldanita (2019) jenisjenis permainan tersebut adalah sebagai berikut.

1. Permainan aktif. Permainan ini dilakukan anak selama permainan yang mereka lakukan menimbulkan kesenangan;

2. Permainan pasif. Kegiatan permainan pasif menuntut anak lebih diam, seperti menyimak, menonton dan membaca;

3. Permainan fantasi. Permainan fantasi adalah kegiatan bermain yang memicu imajinasi yang diciptakan anak sendiri, dan;

4. Permainan tradisional. Permainan tradisional pada umumnya dapat mengembangkan kemampuan bersosialisasi anak. Hal ini dikarenakan permainan tradisional biasanya dimainkan secara bersamasama atau berkelompok.

Alat permainan edukatif diyakini dapat menstimulasi perkembangan anak dengan berbagai potensi yang dimilikinya secara optimal. Kustiawan (2013) berpendapat bahwa alat permainan edukatif merupakan alat bermain yang digunakan anak untuk memenuhi keinginan bermain, sehingga menghasilkan pengertian, memberikan 
informasi, memberikan kesenangan, dan mengembangkan aspek pengembangan pemainnya. Di sisi lain Syamsuardi (2012) berpendapat bahwa alat permainan termasuk sebagai sumber belajar yang sangat diperlukan untuk menstimulasi aspek-aspek perkembangan diri anak usia dini. Ungkapan-ungkapan tersebut menegaskan bahwa selain hanya untuk kesenangan alat permainan edukatif juga dapat menstimulasi perkembangan anak termasuk untuk menstimulasi kecerdasan logis-matematis anak usia 5-6 tahun.

Alat permainan edukatif sebagai media pembelajaran haruslah berkualitas. Menurut Tumardi dan Shopingi (2013) kualitas pembelajaran memiliki tiga komponen penting, yaitu keefektifan pembelajaran, efisiensi pembelajaran, dan kemenarikan pembelajaran. Komponen-komponen ini juga dapat dijadikan aspek-aspek dari indikator kevalidan produk pengembangan, diantaranya yaitu:

1. Keefektifan pembelajaran. Pembelajaran dapat dikatakan efektif jika (hampir semua) anak yang belajar dapat mencapai (hampir semua) tujuan belajar. Keefektifan pembelajaran memiliki indikator berupa: kecermatan penguasaan performansi, kecepatan performansi, kesesuaian dengan prosedur, kualitas performansi, kualitas hasil akhir, tingkat alih/transfer belajar, dan tingkat retensi;

2. Efisiensi pembelajaran. Pembelajaran dinyatakan efisien apabila pencapaian tujuan dan tingkat keefektifan tertentu dapat optimal dengan jumlah waktu, biaya, dan penggunaan yang minimum. Oleh karena itu, alat permainan yang efisien adalah alat permainan yang membutuhkan waktu yang singkat, menggunakan bahan yang murah dan mudah didapat, juga dapat digunakan untuk berbagai macam tujuan, dan;
3. Kemenarikan pembelajaran. Kemenarikan pembelajaran dapat dinyatakan tinggi jika selama dan sesudah pembelajaran berlangsung anak (hampir semua) dapat menggalakkan (membangkitkan) motivasi belajar. Untuk itu kemenarikan pembelajaran memiliki indikator, yaitu: kebertahanan anak untuk menyelesaikan belajar dan keinginan untuk melanjutkan belajar yang lebih jauh.

\section{Kecerdasan Logis-Matematis Anak Usia 5-6 Tahun}

Setiap anak memiliki kecerdasan berbeda-beda. Teori kecerdasan majemuk menyebutkan bahwa anak dapat belajar melalui berbagai macam cara. Menurut Noorlaila (2010) kecerdasan majemuk adalah sebuah penilaian secara deskriptif tentang bagaimana individu menggunakan kemampuannya untuk memecahkan masalah dan menghasilkan sesuatu. Gardner menentang pendapat yang menyatakan bahwa setiap orang hanya memiliki satu kecerdasan (Sukardi dan Astuti, 2013). Selanjutnya Gardner berpendapat bahwa setiap orang memiliki delapan potensi kecerdasan di mana antara kecerdasan yang satu dengan kecerdasan yang lain memiliki pengaruh yang saling berkaitan dan tidak bisa berdiri sendiri. Salah satu dari kedelapan potensi kecerdasan tersebut adalah kecerdasan logis-matematis.

Kecerdasan logis-matematis merupakan salah satu kecerdasan majemuk yang berfokus pada lingkungan logika, matematika, dan sains. Campbell, Campbell, dan Dickinson (2004) mengemukakan "Gardner describe logical-mathematical intelligence as encompassing many kinds of thingking. He suggests that this intelligences encompasses three broad, but interrelated field: mathematic, sciences and logic". Menurut Musfiroh (2005) anak yang memiliki kemampuan logismatematis cenderung tertarik 
memanipulasi lingkungan serta cenderung suka menerapkan stretegi coba-ralat dan suka menduga-duga sesuatu. Begitu pula Noorlaila (2010) menyatakan bahwa kecerdasan logismatematis ditandai dengan kemampuan berpikir konseptual yang menyebabkan individu mampu berpikir dengan baik, suka mengeksplorasi pola, kategori dan hubungan. Ungkapan tersebut mengartikan bahwa kecerdasan logismatematis merupakan kemampuan matematika, sains dan logika yang saling berkaitan. Seseorang dengan kecerdasan logis-matematis cenderung memiliki kemampuan berpikir dan menggunakan simbol abstrak, bernalar induktif/deduktif, dan memiliki kemampuan dalam bidang numerik.

Anak yang memiliki kecerdasan logis-matematis cenderung memiliki ciriciri tertentu. Suyadi dan Dahlia (2015) mengelompokkan ciri-ciri anak yang memiliki kecerdasan logis-matematis berdasarkan tingkatan usia salah satunya adalah tingkatan usia 5-6 tahun, yaitu: mampu mengurutkan bilangan 1-50; senang dengan permainan otak-atik bilangan; menyukai permainan strategi, dan; dapat dengan mudah meletakkan benda sesuai dengan kelompoknya. Pendapat Suyadi dan Dahlia tersebut berkaitan dengan indikator perkembangan kognitif anak usia 5-6 tahun. Keterkaitan indikator kecerdasan logis-matematis dengan indikator perkembangan kognitif tersebut mengartikan pentingnya stimulasi kecerdasan logis-matematis terhadap aspek perkembangan kognitif anak. Hal ini dikarena potensi kecerdasan logismatematis dapat berpengaruh terhadap kemampuan akademis anak nantinya.

\section{Alat Permainan Kartu $\boldsymbol{U}$-Kids}

Kartu U-Kids adalah alat permainan grafis yang menyajikan warna, angka, gambar dan juga simbol yang dirancang untuk menstimulasi kecerdasan logis-matematis anak usia 5-6 tahun. Kartu $U$-Kids ini merupakan jenis alat permainan aktif karena dapat menstimulasi anak untuk bermain dengan menyelidik sehingga membutuhkan strategi dengan indikator: menyusun secara serial kategori, dan hirearkial; memiliki kepekaan terhadap angka; memahami simbol angka dan pembilang dengan cepat, dan; dapat menganalisis benda-benda dengan cepat.

\section{METODOLOGI PENELITIAN}

Penelitian dan pengembangan ini menggunakan model pengembangan ADDIE yang terdiri dari lima tahap prosedur pengembangan, yaitu analisis, desain, pengembangan, penerapan, dan evaluasi. Desain uji coba pertama-tama dilakukan oleh para ahli yang kemudian dilanjutkan dengan uji coba oleh para pengguna pada saat kegiatan pembelajaran anak usia 5-6 tahun. Selain itu penelitian dan pengembangan ini juga menggunakan dua jenis instrumen pengumpulan data, yaitu angket validasi dan catatan observasi ketika uji coba. Data yang sudah dikumpulkan kemudian dianalisis menggunakan teknik analisis deskriptif kuantitatif dan deskriptif kualitatif untuk mengetahui hasil yang diperoleh.

\section{HASIL PENELITIAN DAN PEMBAHASAN}

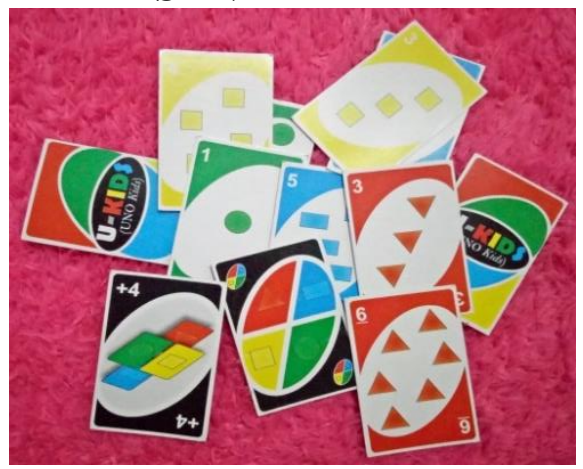

Gambar 2. Kartu U-Kids

Bukan hanya sebagai alat permainan, kartu U-Kids juga dapat dijadikan sebagai media pembelajaran bagi lembaga PAUD. Oleh karena itu, kartu U-Kids ini dirancang dengan 
memperhatikan indikator kecerdasan logis-matematis yang berkaitan dengan indikator perkembangan kognitif anak usia 5-6 tahun agar dapat membantu guru dalam penyampaian materi pembelajaran.

Desain kartu U-Kids terdiri dari gambar, kartu, panduan bermain dan cover produk. Dalam pengemabangan alat permainan kartu $U$-Kids menggunakan aplikasi Corel Draw X7. Desain gambar yang dimaksud adalah gambar geometri (segitiga, persegi, lingkaran dan persegi panjang), blokir dan putar balik yang dimuat pada kartu. Pembuatan kartu pada tahap ini adalah mengatur ukuran kartu yaitu $8,5 \mathrm{~cm}$ x 5,5 $\mathrm{cm}$ dengan desain warna yang berbeda. Desain panduan bermain dibuat menjadi sebuah buku kecil berukuran $5,5 \mathrm{~cm} \times$ $8,5 \mathrm{~cm}$ dengan jumlah halaman sebanyak 28 lembar. Desain cover (bungkus/wadah) memiliki ukuran 5,5 $\mathrm{cm} \times 7,5 \mathrm{~cm} \times 8,5 \mathrm{~cm}$ dengan tujuan memudahkan pengguna untuk menyimpan alat permainan kartu $U$-Kids.

Berikut adalah desain jenis-jenis kartu $U$-Kids dan kegunaannya.

1. Kartu +4 Sakti

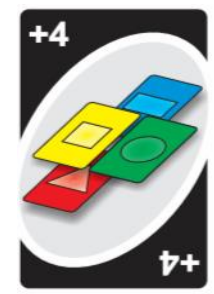

Gambar 3. Kartu +4 sakti

Kartu +4 sakti hanya dapat digunakan untuk bermain seperti kartu UNO pada umumnya. Pada saat bermain kartu +4 sakti dapat dipasangkan setelah kartu apapun yang dipasangkan di Gunung U-Kids, sedangkan pemain selanjutnya harus mengambil 4 buah kartu dari pohon $U$-Kids atau boleh memasangkan kartu yang sama untuk membayarnya. Selain itu, pemain yang memasangkan kartu +4 sakti berhak menentukan warna apa yang harus dipasangkan oleh pamain 'kedua' selanjutnya.

\section{Kartu Bulat Sakti}

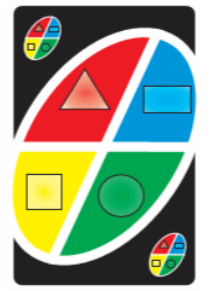

Gambar 4. Kartu bulat sakti

Kartu bulat sakti hanya dapat digunakan untuk bermain seperti kartu UNO pada umumnya. Pada saat bermain kartu bulat sakti dapat dipasangkan setelah kartu apapun yang dipasangkan di Gunung $U$-Kids dan berhak menentukan warna apa yang harus dipasangkan oleh pamain selanjutnya.

\section{Kartu Putar Balik}
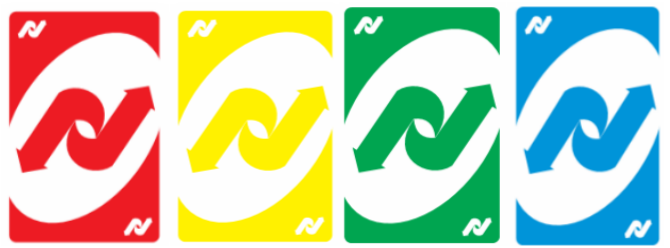

Gambar 5. Kartu putar balik

Kartu putar balik dapat digunakan untuk dua cara bermain, yaitu bermain mengelompokkan warna dan bermain seperti kartu UNO pada umumnya. Pada saat bermain kartu putar balik dapat dipasangkan setelah kartu yang berwarna/bersimbol sama dipasangkan di Gunung U-Kids. Jika kartu ini dipasangkan maka alur permainan berputar balik pada pemain sebelumnya.

\section{Kartu Blokir}
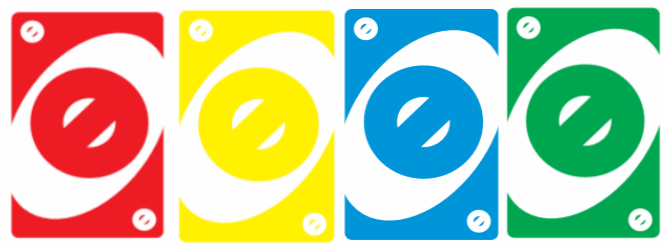

Gambar 6. Kartu blokir

Kartu blokir dapat digunakan untuk dua cara bermain, yaitu bermain mengelompokkan warna dan bermain seperti kartu UNO pada umumnya. Pada saat bermain kartu blokir dapat dipasangkan setelah kartu yang berwarna/bersimbol sama dipasangkan di 
Gunung $U$-Kids, sedangkan satu pemain selanjutnya tdak boleh bermain dan dilanjutkan oleh pemain 'kedua' selanjutnya.

5. Kartu +2
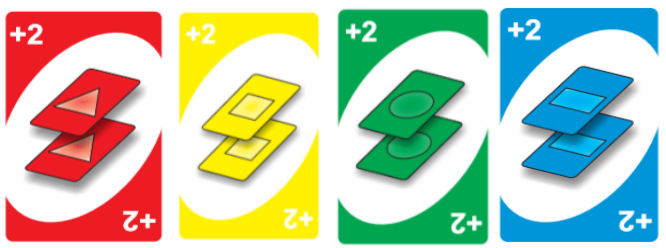

Gambar 7. Kartu +2

Kartu +2 dapat digunakan untuk dua cara bermain, yaitu bermain mengelompokkan warna dan bermain seperti kartu UNO pada umumnya. Pada saat bermain kartu +2 dapat dipasangkan setelah kartu yang berwarna/bersimbol sama dipasangkan di Gunung U-Kids, sedangkan satu pemain selanjutnya tdak boleh bermain dan harus mengambil 2 buah kartu tambahan di pohon U-Kids, kemudian dilanjutkan oleh pemain 'kedua' selanjutnya dengan memasang kartu yang berwarna/bersimbol sama.

6. Kartu angka (0-9)

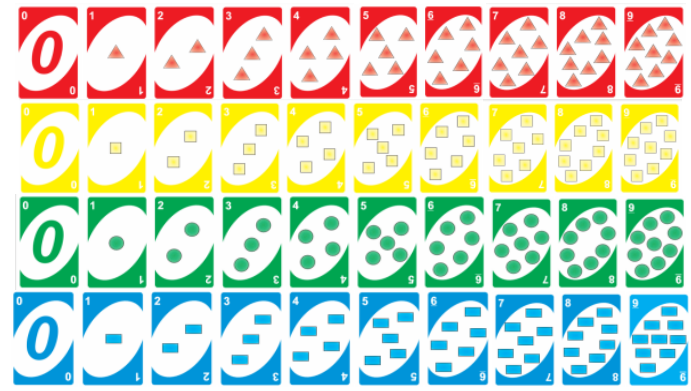

Gambar 8. Kartu angka

Kartu ini dapat digunakan untuk bermain mengelompokkan warna, mengurutkan angka dan bermain seperti kartu UNO pada umumnya. Pada saabermain kartu UNO pada umumnya kartu angka ini dapat dipasangkan setelah kartu yang dipasangkan di Gunung $U$ Kids merupakan kartu yang memiliki angka atau warna yang sama.

Alat permainan kartu $U$-Kids yang dirancang untuk menstimulasi kecerdasan logis-matematis anak usia 5-6 tahun juga dapat mensitimulai perkembangan lain, yaitu perkembangan bahasa. Stimulasi-stimulasi tersebut dapat dilihat dari garis besar cara bermainnya sebagai berikut.

1. Memiliki kepekaan terhadap angka dengan memahami konsep 'lebih dari' dan 'kurang dari' pada saat mengelompokkan warna.

2. Menyusun secara serial, kategorial dan hirearkial melalui bermain mengurutkan bilangan cacah menggunakan kartu dan mengolompokkan kartu sesuai dengan warna.

3. Menganalisis benda-benda dengan cepat melalui menganalisis jenisjenis kartu dalam kegiatan bermain.

4. Memahami simbol angka dan membilang pada saat menyusun secara serial dengan menghitung banyaknya jumlah gambar dan simbol pada kartu.

5. Menstimulasi aspek perkembangan bahasa dengan memahami bahasa reseftif melalui aturan permainan.

Kartu $U$-Kids memiliki tiga cara bermain, yaitu mengelompokkan warna, mengurutkan angka dan bermain seperti kartu UNO pada umumnya. Gambarannya adalah sebagai berikut.

\section{Mengelompokkan warna}

Bermain mengelompokkan warna merupakan salah satu kegiatan stimulasi yang sering dijumpai di beberapa lembaga PAUD. Hal ini dikarenakan bermain mengelompokkan warna adalah salah satu tahap awal bagi anak usia dini dalam mengenal angka. D'Augustin (1992) “...kindergarten classes are filled with activities that can be used to strengthen a child's conseptual understanding of classification", maksudnya adalah semua taman kanakkanak dapat menggunakan kegiatan untuk memperkuat pemahaman anak tentang konsep klasifikasi. Kegiatan mengelompokkan warna dapat dilakukan dengan berbagai cara, salah satunya adalah bermain mengelompokkan warna kartu U-Kids. Dalam bermain 
mengelompokkan warna permainan dapat dilakukan secara individu ataupun kelompok. Jika dimainkan secara kelompok maka buatlah empat kelompok dengan nama sesuai dengan warna kartu (kelompok merah, kelompok kuning, kelompok, hijau dan kelompok biru). Pada saat bermain mengelompokkan warna kartu +4 sakti dan kartu bulat sakti tidak digunakan. Mulailah permainan dengan mencampurkan kartu berwarna merah, kuning, hijau dan biru. Kemudian ajaklah anak menggelompokkan kartu dengan warna yang sama.

\section{Bermain mengurutkan angka} Mengurutkan angka dapat mensimulasi anak dalam keterampilan berhitungnya. D'Augustin (1992) juga menyebutkan bahwa "without the rote counting skill, children inevitably 'miscount' a set of object because one word of the number sequence is missing", maksudnya tanpa keterampilan berhitung anak akan mengalami kesalahan dalam menyebutkan satu set bilangan karena tidak menyebutkan urutan angka dengan benar (missal: satu, dua, empat, lima, enam). Untuk itu bermain mengurutkan angka dengan kartu U-Kids dapat menstimulasi keterampilan tersebut. Kartu yang digunakan hanyalah kartu angka dari masing masing kartu berwarna merah, kuning, hijau dan biru. Cara bermainnya adalah menyusun kartu berdasakan angka dari yang terkecil sampai yang terbesar atau sebaliknya, dari yang terbesar ke yang terkecil.

3. Bermain Kartu U-kids seperti bermain kartu UNO pada umumnya

Cara bermainnya adalah: pertamabuatlah satu kelompok bermain sekitar 25 pemain dengan duduk melingkar (jika anak belum memahami permainan maka dampingilah anak bermain); buatlah kesepakatan siapa yang memulai permainan dan tentukan alur permainannya (searah jarum jam atau sebaliknya); kocoklah semua kartu (berilah setiap anak kesempatan mengocok dengan membagi 1 set kartu sesuai jumlah pemain, kemudian satukan kembali); berilah masing-masing pemain 5 buah kartu; letakkan sisanya di tengahtengah para pemain sebagai 'Pohon $U$ Kids' dengan posisi tertutup.

Pada permulaan permainan, ambilah satu kartu dari 'Pohon U-Kids' dan letakan terbuka ditengah-tengah para pemain sebagai 'Gunung $U$-kids'. Pemain yang sudah ditentukan untuk bermain bertugas memasang kartu dengan warna/angka/simbol yang sama dengan kartu yang terakhir di pasang di 'Gunung U-Kids'. Selanjutnya lakukan hal yang sama. Jika pemain tidak memiliki kartu yang sama dengan kartu yang terakhir dipasang di Gunung U-Kids maka pemain tersebut harus mengambil kartu tambahan yang berada di Pohon U-kids, tanpa harus memasangkan pada Gunung U-Kids, kemudian anjutkan dengan pemain selanjutnya. Permainan berlangsung hingga para pemain tidak memiliki kartu lagi. Pemain yang pertama menghabiskan kartu yang dimilikinya adalah pemenang dari permainan ini, begitu pun seterusnya.

$$
\text { Kartu U-Kids ini memiliki }
$$
kelebihan yang cukup banyak, diantaranya: disesuaikan dengan indikator kecerdasan logis-matematis dan capaian perkembangan kognitif anak usia 5-6 tahun; memiliki beberapa kartu sakti dan kartu yang berisi simbol yang dapat menstimulasi anak untuk mengatur strategi permainan; dapat diguanakan sebagai media pembelajaran dan dapat menjadi alat permainan edukatif yang menyenangkan bagi keluarga.; aturan permainan atau cara bermain kartu $U$ Kids dapat menstimulasi kecerdasan logis-matematis anak, dimana anak akan distimulasi mengenai kemampuan mencocokan warna, mencocokan bentuk, mengurutkan angka dengan mengatur strategi permainan, dan; dapat dimainkan secara individu dan kelompok. 
Di balik kelebihannya kartu $U$ Kids memiliki kekurangan. Kekurangan yang dimaksud yaitu hanya memiliki satu tema gambar. Tema yang dimaksud adalah tema geometri. Walaupun lebih available tema geometri dirasa akan kalah menarik jika dibandingkan tema buah-buahan, binatang atau gambar menarik lainnya.

Kartu U-Kids yang sudah dikembangkan kemudian melewati tahap evaluasi formatif untuk mengetahui kekurangan dan kesalahan dalam proses pengembangannya. Evaluasi formatif ini diperoleh dari validasi para ahli dan validasi para pengguna. Proses validasi oleh para ahli dilakukan oleh 2 ahli materi dan 2 ahli media, sedangkan pada proses validasi para pengguna dilakukan oleh guru yang diperoleh melalui uji coba dengan melibatkan sejumlah subjek (uji coba perorangan melibatkan 3 subjek dengan 1 guru, uji coba kelompok kecil melibatkan 12 subjek dengan 1 guru dan uji coba kelompok besar melibatkan 41 subjek dengan 2 guru).

Hasil validasi didapatkan dari lembar validasi yang terdiri dari 19 indikator dengan rentang skor 1-5. Indikator yang dimaksud terdiri dari komponen penting media pembelajaran yang berkualitas yaitu aspek keefektifan, aspek keefisienan dan aspek kemenarikan. Aspek keefektifan memiliki 6 indikator, aspek keefisienan memiliki 7 indikator dan aspek kemenarikan memiliki 6 indikator.

Lembar validasi para ahli dan para pengguna masing masing berbeda. Lembar validasi ahli materi hanya terdiri terdiri dari aspek keefektifan dengan 6 indikator.Lembar validasi ahli media terdiri dari aspek keefisienan dan aspek kemenarikan, masing-masing aspek memiliki 7 indikator dan 6 indikator. Sedangkan, lembar validasi para pengguna terdiri dari semua aspek dengan 19 indikator.

Data yang diperoleh dari hasil validasi kemudian dianaisis menggunakan rumus-rumus yang diadaptasi dari Akbar (2013: 18)berikut.

Validasi aspek keefektifan:

$$
\mathrm{V}_{\mathrm{AEfk}}=\frac{\sum \mathrm{Tse}}{\sum \mathrm{Tsh}} \times 100 \%
$$

Validasi aspek keefisienan:

$$
\mathrm{V}_{\text {AEfs }}=\frac{\sum \text { Tse }}{\sum \text { Tsh }} \times 100 \%
$$

Validasi aspek kemenarikan:

$$
\mathrm{V}_{\mathrm{AKmn}}=\frac{\sum \mathrm{Tse}}{\sum \mathrm{Tsh}} \times 100 \%
$$

Validasi keseluruhan:

$$
\mathrm{V}=\frac{\sum \mathrm{Tse}}{\sum \mathrm{Tsh}} \times 100 \%
$$

Keterangan:

$\mathrm{V}_{\mathrm{AEfk}}=$ Validitas aspek keefisienan

$\mathrm{V}_{\mathrm{AEfs}}=$ Validitas aspek keefisienan

$\mathrm{V}_{\mathrm{AKmn}}=$ Validitas aspek kemenarikan

$\mathrm{V} \quad=$ Validitas keseluruhan

$\sum$ Tse $=$ Total skor empirik (masing-masing aspek)

$\sum$ Tsh $=$ Total skor yang diharapkan (masing-masing aspek)

$100 \%=$ Konstanta

Hasil analisis data persentase dari rumus-rumus di atas diperoleh interpretasi, yaitu penafsiran terhadap analisis data pengguna mengenai kelayakan produk yang dikembangkan. Produk yang dikembangan dikatakan layak apabila mencapai minimal angka $61 \%$. Untuk mengetahui interpretasi

\begin{tabular}{|c|c|c|c|c|}
\hline \multirow{2}{*}{$\begin{array}{c}\text { Kriteria } \\
\text { Pencapaian } \\
\text { Nilai }\end{array}$} & \multicolumn{4}{|c|}{ Tingkatan Validitas } \\
\hline & $\begin{array}{l}\text { Keselu- } \\
\text { ruhan }\end{array}$ & $\begin{array}{c}\text { Efekti- } \\
\text { fitas }\end{array}$ & $\begin{array}{c}\text { Efisi- } \\
\text { ensi }\end{array}$ & $\begin{array}{c}\text { Keme- } \\
\text { narikan }\end{array}$ \\
\hline $\begin{array}{l}81,00 \%- \\
100,00 \% \\
\end{array}$ & $\begin{array}{l}\text { Sangat } \\
\text { valid }\end{array}$ & $\begin{array}{l}\text { Sangat } \\
\text { efektif }\end{array}$ & $\begin{array}{l}\text { Sangat } \\
\text { efisien }\end{array}$ & $\begin{array}{l}\text { Sangat } \\
\text { menarik }\end{array}$ \\
\hline $\begin{array}{l}61,00 \%- \\
80,00 \%\end{array}$ & $\begin{array}{l}\text { Cukup } \\
\text { valid }\end{array}$ & $\begin{array}{l}\text { Cukup } \\
\text { efektif }\end{array}$ & $\begin{array}{l}\text { Cukup } \\
\text { efisien }\end{array}$ & $\begin{array}{l}\text { Cukup } \\
\text { menarik }\end{array}$ \\
\hline $\begin{array}{c}41,00 \%- \\
60,00 \%\end{array}$ & $\begin{array}{l}\text { Kurang } \\
\text { valid }\end{array}$ & $\begin{array}{l}\text { Kurange } \\
\text { fektif }\end{array}$ & $\begin{array}{l}\text { Kurang } \\
\text { efisien }\end{array}$ & $\begin{array}{l}\text { Kurang } \\
\text { menarik }\end{array}$ \\
\hline $\begin{array}{c}21,00 \%- \\
40,00 \%\end{array}$ & $\begin{array}{l}\text { Tidak } \\
\text { valid }\end{array}$ & $\begin{array}{l}\text { Tidak } \\
\text { efektif }\end{array}$ & $\begin{array}{l}\text { Tidak } \\
\text { efisien }\end{array}$ & $\begin{array}{l}\text { Tidak } \\
\text { menarik }\end{array}$ \\
\hline $\begin{array}{c}00,00 \%- \\
20,00 \%\end{array}$ & $\begin{array}{l}\text { Sangat } \\
\text { tidak } \\
\text { valid }\end{array}$ & $\begin{array}{l}\text { Sangat } \\
\text { tidak } \\
\text { efektif }\end{array}$ & $\begin{array}{l}\text { Sangat } \\
\text { tidak } \\
\text { efisien }\end{array}$ & $\begin{array}{l}\text { Sangat } \\
\text { tidak } \\
\text { menarik }\end{array}$ \\
\hline
\end{tabular}
mengenai kelayakan produk tersebut digunakan kriteria sebagai berikut.

Tabel 1.Persentase Kriteria Validitas 
Hasil validasi para ahli dan para pengguna kemudian diakumulasikan. Sebelumnya sudah diketahui bahwa aspek keefektifan yang berjumlah 6 indikator divalidasi oleh 2 validator ahli dan 4 validator pengguna,aspek keefisienan yang berjumlah 7 indikator juga divalidasi oleh 2 validator ahli dan 4 validator pengguna, begitupun aspek kemenarikan yang berjumlah 6 indikator divalidasi oleh 2 validator ahli dan 4 validator pengguna, sehingga menghasilkan data berikut.

Tabel 2.Skor Validasi

\begin{tabular}{|c|c|c|c|c|}
\hline \multirow{2}{*}{ Aspek } & \multicolumn{2}{|c|}{ Skor Validator } & \multicolumn{2}{|c|}{ Skor } \\
\hline & Ahli & Pengguna & $\sum$ Tse & $\sum$ Tsh \\
\hline Keefektifan & 56 & 110 & 166 & 180 \\
\hline Keefisienan & 61 & 130 & 191 & 210 \\
\hline Kemenarikan' & 51 & 109 & 160 & 180 \\
\hline Keseluruhan (total) & 168 & 349 & 517 & 570 \\
\hline
\end{tabular}

Berdasarkan data di atas untuk mengetahui tingkat validitas keefektifan maka dianalisis seperti berikut.

$\mathrm{V}_{\text {AEfk }}=\frac{\sum \text { Tse }}{\sum \text { Tsh }} \times 100 \%$

$\mathrm{V}_{\text {AEfk }}=\frac{166}{180} \times 100 \%$

$\mathrm{V}_{\mathrm{AEfk}}=92,22 \times 100 \%$

$\mathrm{V}_{\mathrm{AEfk}}=92,22 \%$

Hasil tersebut menunjukkan bahwa alat permainan kartu U-Kids memiliki pencapaian nilai sebesar 92,22\% yang menurut Tabel.1 mencapai tingkat validitas sangat efektif. Kemudian untuk mengetahui tingkat validitas keefisienan maka dapat dianalisis dengan cara:

$\mathrm{V}_{\mathrm{AEfs}}=\frac{\sum \mathrm{Tse}}{\sum \mathrm{Tsh}} \times 100 \%$

$\mathrm{V}_{\mathrm{AEfs}}=\frac{191}{210} \times 100 \%$

$\mathrm{V}_{\mathrm{AEfs}}=90,95 \times 100 \%$

$\mathrm{V}_{\mathrm{AEfs}}=90,95 \%$

Hasilnya menunjukkan bahwa alat permainan kartu U-Kids memiliki pencapaian nilai sebesar $90,95 \%$ yang menurut Tabel.1 mencapai tingkat validitas sangat efisien. Sedangkan untuk mengetahui tingkat validitas kemenarikan maka dapat dianalisis dengan cara:

$\mathrm{V}_{\mathrm{AKmn}}=\frac{\sum \mathrm{Tse}}{\sum \mathrm{Tsh}} \times 100 \%$

$\mathrm{V}_{\mathrm{AKmn}}=\frac{160}{180} \times 100 \%$

$\mathrm{V}_{\mathrm{AKmn}}=88,88 \times 100 \%$

$\mathrm{V}_{\mathrm{AKmn}}=88,88 \%$

Hasil dari proses analisis tersebut menunjukkan bahwa alat permainan kartu $U$-Kids memiliki pencapaian nilai sebesar $88,88 \%$ yang menurut Tabel.1 mencapai tingkat validitas sangat menarik. Selanjutnya untuk mengetahui tingkat validitas keseluruhan maka dapat dianalisis dengan cara:

$\mathrm{V}=\frac{\sum \mathrm{Tse}}{\sum \mathrm{Tsh}} \times 100 \%$

$\mathrm{V}=\frac{517}{570} \times 100 \%$

$\mathrm{V}=90,7 \times 100 \%$

$\mathrm{V}=90,7 \%$

Hasil analisis validasi keseluruhan menunjukkan bahwa alat permainan kartu U-Kids memiliki pencapaian nilai sebesar $90,7 \%$ yang menurut Tabel.1 mencapai tingkat validitas sangat valid.

Berdasarkan hasil analisis diatas dapat disimpulkan bahwa alat permainan kartu $U$-Kids sangat layak digunakan. Di samping itu, alat permainan kartu $U$-Kids juga mengalami perbaikan pada dua bagian sebagaimana saran dari para ahli sebelum diujicobakan kepada para pengguna. Perbaikan tersebut yaitu:

1. Mengganti warna kartu simbol kartu skip/blokir dan kartu u-turn/putar agar terlihat lebih jelas untuk anak

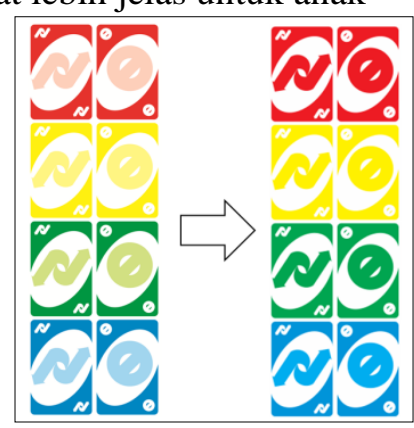


Gambar 9.Simbol kartu skip/blokir dan kartu $u$ turn/putar balik sebelum dan sesudah direvisi

2. Bagian panduan permainan yang diperbaiki agar lebih mudah dipahami pengguna.

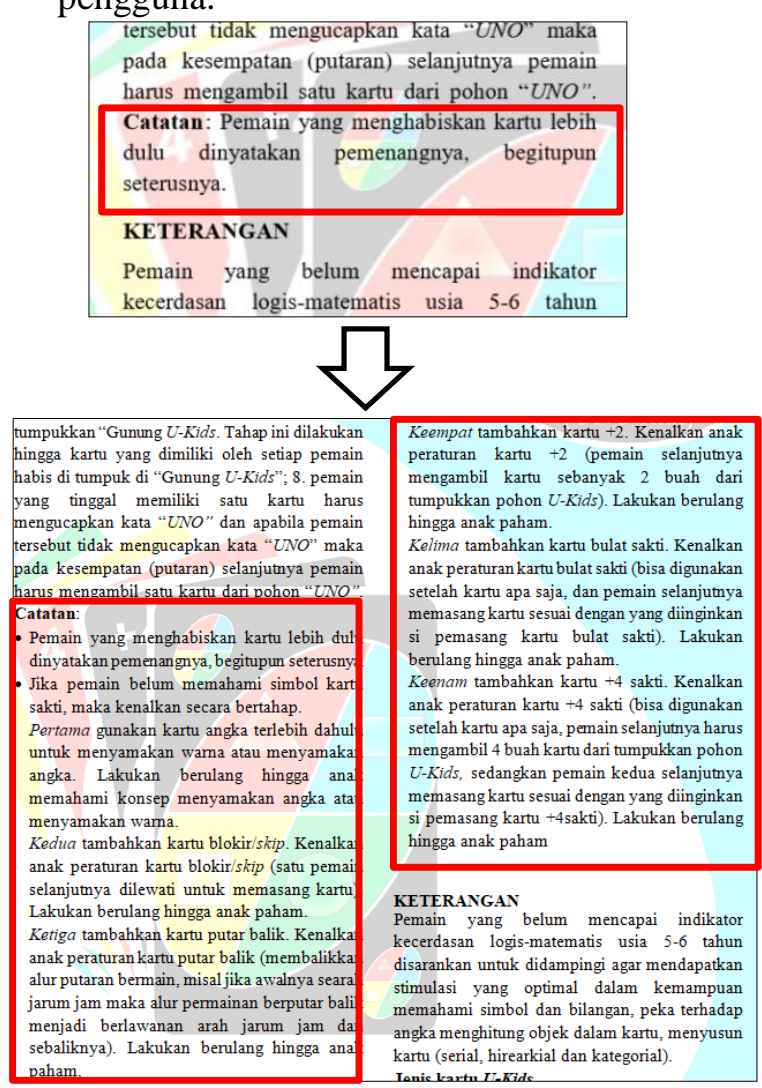

Gambar 10. Panduan bermain sebelum \& sesudah direvisi

Penggunaan objek geometri memang lebih available, namun akan lebih baik jika objek yang digunakan memiliki karakter yang lebih menarik. Untuk itu, peneliti menyarankan agar pengembangan ini dapat dibuat dengan objek berbagai macam tema yang ada di lembaga PAUD secara umum agar lebih menarik. Oleh karena itu, pada saat uji coba peneliti juga mendapatkan saran dari pengguna ketika melakukan uji coba kelompok besar, untuk membuat $U$-kids dengan objek gambar, seperti buahhuahan atau binatang.

\section{KESIMPULAN}

Penelitian dan pengembangan ini menunjukan bahwa kartu U-Kids memiliki persentase kelayakan sebesar
91,27\% (sangat layak) dengan aspek keefektifan sebesar 93,05\% (sangat efektif), aspek keefisienan 90,47\% (sangat efisien) dan aspek kemenarikan $89,16 \%$ (sangat menarik). Berdasarkan hasil tersebut dapat disimpulkan bahwa pengembangan alat permainan kartu $U$ Kids untuk menstimulasi kecerdasan logis-matematis anak usia 5-6 tahun sangat valid (layak) dari segi efektifitas, efisiensi dan kemenarikan. Alat permainan kartu $U$-Kids yang telah dikembangkan terbatas pada objek geometri. Penggunaan objek geometri memang lebih available, namun akan lebih baik jika objek yang digunakan memiliki karakter yang lebih menarik. Untuk itu, peneliti menyarankan agar pengembangan ini dapat dibuat dengan objek berbagai macam tema yang ada di lembaga PAUD secara umum agar lebih menarik.

\section{DAFTAR PUSTAKA}

Akbar, Sa'dun. (2013). Instrumen Perangkat Pebelajaran. Bandung: PT. Remaja Rosdakarya.

Campbell, Linda, Bruce Campbell, dan Dee Dickinson. (2004). Teaching And Learning Through Multiple Intelligences. 3 ed. Boston: Pearson Education, Inc.

D'Augustin, Charles H. (1992). Teaching Elementary School Mathematics. New York: HyperCollins Publisher Data.

Hidayati, Nurul. (2014). "Pengembangan Permainan Kartu UNO Sebagai Alat Evaluasi Pembelajaran Akuntansi Pokok Bahasan Hutang Jangka Panjang." Jurnal Pendidikan Akuntansi 3 (2). https://jurnalmahasiswa.unesa.ac.id/i ndex.php/jpak/article/view/9060.

Hidayatu, Munawaroh. (2017).

"Pengembangan Model

Pembelajaran dengan Permainan Tradisional Engklek Sebagai Sarana 
Stimulasi Perkembangan Anak Usia Dini." Jurnal Obsesi: Jurnal Pendidikan Anak Usia Dini 01 (02). https://obsesi.or.id/index.php/obsesi/ article/view/19.

Hurlock, Elizabeth B. (1978). Jilid 1: Perkembangan Anak. Diedit oleh M. M. Tjandrasa dan Muchlichah Zarkasih. Terjemahan. Jakarta: Erlangga.

Jasmin, Julia. (2001). Metode Mengajar Multiple Intelligences. Diedit oleh Purwanto. Terjemahan. Bandung: NUANSA.

Kustiawan, Usep. (2013). Sumber dan Media Pembelajaran Anak Usia Dini. Malang: Fakultas Ilmu Pendidikan Universitas Negeri Malang.

Musfiroh, T. (2014). Pengembangan Kecerdasan Majemuk. Hakikat Kecerdasan Majemuk (Multiple Intelegences). $\quad$ Vol. 60. http://repository.ut.ac.id/4713/2/PA UD4404-TM.pdf.

Musfiroh, Takdiroatun. (2005). Bermain Sambil Belajar dan Mengasah Kecerdasan. Jakarta: Depdiknas Dirjen Dikti Direktorat Pembinaan Pendidikan Tenaga Kependidikan dan Ketenagaan Perguruan Tinggi.

Noorlaila, Iva. (2010). Panduan Lengkap Mengajar PAUD. Diedit oleh Achmad Cahyanto. Yogyakarta: Pinus Book Publisher.

Purnama, Sigit, Y.S. Hijriyani, dan Heldanita. (2019). Pengembangan Alat Permainan Edukatif Anak Usia Dini. Bandung: PT. Remaja Rosdakarya.

Sukardi, M., dan Wuri Astuti. (2013). Kajian Perkembangan Kognitif Anak Usia Dini. Malang: Fakultas Ilmu Pendidikan Universitas Negeri Malang.

Suyadi, dan Dahlia. (2015).

$\begin{array}{lcr}\text { Omplementasi } & \text { dan } & \text { Inovasi } \\ \text { Kurikulum } & \text { PAUD } & 2013 . \\ \text { Yogyakarta: } & \text { PT. } & \text { Remaja } \\ \text { Rosdakarya. } & & \end{array}$

Syamsuardi. (2012). "Pengunaan Alat Permainan Edukatif (APE) di Taman Kanak-Kanak PAUD Polewali Kecamatan Tanete Riattang Barat Kabupaten Bone." Jurna Publikasi Pendidikan 11 (1): 59-67. http://ojs.unm.ac.id/.

Tumardi, dan Shopingi. (2013). Belajar dan Pembelajaran. Malang: Fakultas Ilmu Pendidikan Universitas Negeri Malang.

Witantyo, Maulana. (2017). "Pengembangan Media Pembelajaran Kartu UNO Akuntansi Untuk Meningkatkan Motivasi Belajar Siswa Kelas X Akuntansi 4 SMK YPKK 2 Sleman Tahun Ajaran 2016/2017." Universitas Negeri Yogyakarta. https://eprints.uny.ac.id/52254/1/Skr ipsi_MaulanaWitantyo_1380324100 8.pdf. 